\title{
Non-CFC Vacuum Alternatives for the Energy-Efficient Insulation of Household Refrigerators: Design and Use
}

Thomas F. Potter

Davld K. Benson

Solar Energy Research Institute

Golden, Colorado 80401

January 1991

preprint of article for

Proceedings, 42nd Intemational

Technical Conference

Madison, Wisconsin

May 1991

Solar Energy Research Institute

A Division of Midwest Research Institute

1617 Cole Boulevard

Golden, Colorado 80401-3393

Prepared for the

U.S. Department of Energy

Contract No. DE-AC02-83CH10093 


\title{
Non-CFC Vacuum Alternatlves for Energy-Efficlent Insulation of Household Refrigerators: Design and Use
}

\author{
Thomas F. Potter and David K. Benson \\ Solar Energy Research Institute (SERI) \\ 1617 Cole Boulevard: (303) 231-1083 \\ Golden, Colorado 80401
}

\begin{abstract}
Energy efficiency, environmental issues, and market incentives all encourage government and industry to continue work on thin-profile vacuum insulations for domestic refrigerators and freezers (R/Fs). Vacuum insulations promise significant improvement in thermal savings over current insulations; the techical objective of one design is an $\mathrm{R}$-value of better than 10 (hr- $\mathrm{tr}-\mathrm{F} / \mathrm{Btu})$ in 0.1 in. thickness. If performance is improved by a factor of 10 over that of $\mathrm{CFC}$-blown insulating foams, the new insulations (made without CFCs or other potentially troublesome fill gases) will change the design and improve the efficiency of refrigerators. Such changes will meet the conservation, regulatory, and market drivers now strong in developed countries and likely to increase in developing countries. Prototypes of various designs have been tested in the laboratory and in factories, and results to date confirm the good thermal performance of these thin-profile altematives. The next stap is to resolve issues of reliability and cost effectiveness.
\end{abstract}

\section{INTRODUCTION}

Interest in energy conservation is widespread becautse of imporant environmental and economic factors, including the threat of global warming and energy insecurity caused by wasteful energy use. Household refrigerators and freezers (R/Fs) insulated with CFC-blown foam use considerable elestricity. These insulating systems, and the appliances that use them, have become more efficient and still are improving incrementally. However, a number of innovarive vacuum-insulation concepts now being developed can provide very large reductions of unwanted thermal transfer. These ne $\%$ insulations are likely to greatly improve the energy-efficient design and operation of household R/Fs over the next ten years with little or no loss of utility or cost increase. These benefits may result from studies now under way in the design and fabrication cf vacuum insulations, which promise to improve energy efficiency, reduce negative environmental impacts, and increase consumer utility of the household $R / F$.

This paper reviews the background for such technical developments, describes applications for vacuum insulations in the appliance market, and considers the current starus of several promising technologies. Designs of alternative refrigerator sidewalls that these technologies may enable are also discussed.

Please see last page for S.I. conversicns. 


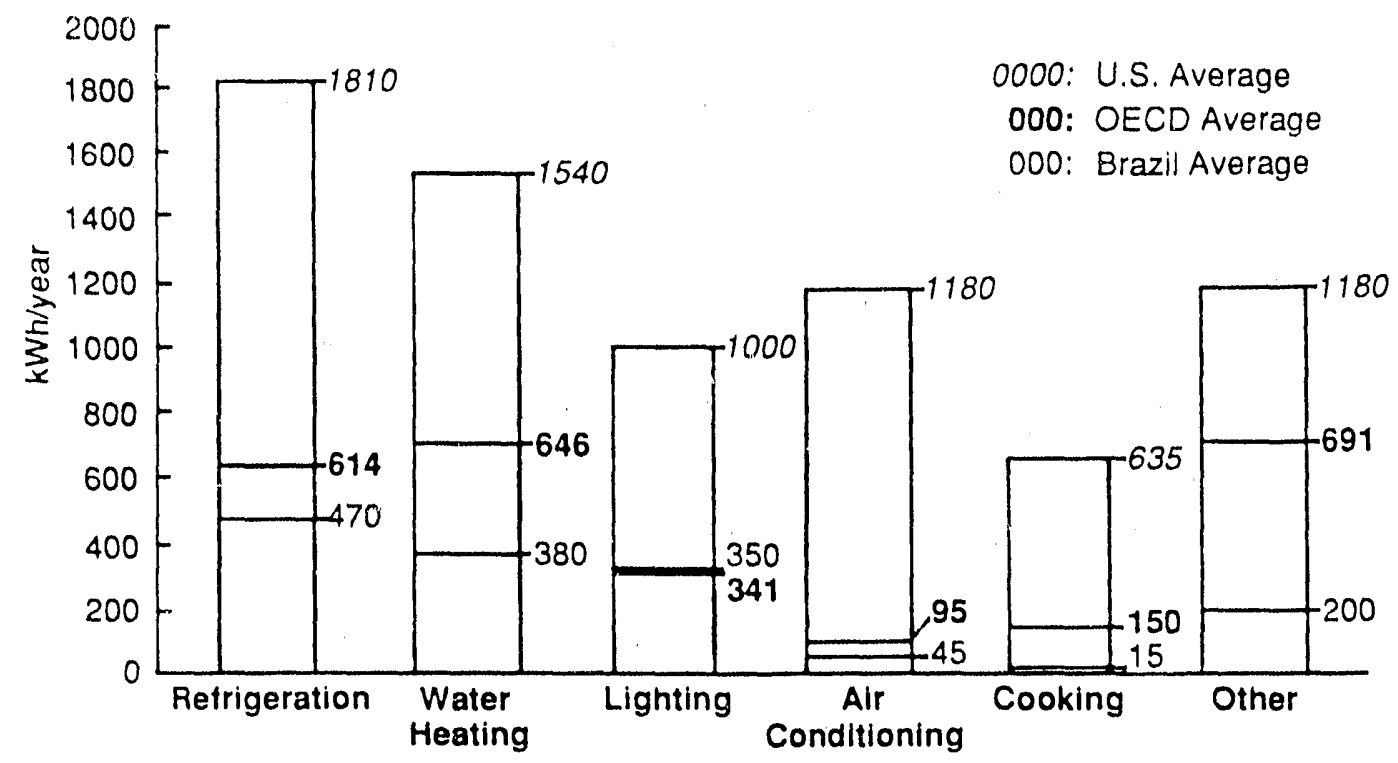

Figure 1. Average residential electricity use in the United States, Brazil, and three industrialized countries, showing great similarities in end-use distribution. $O E C D$ (Organization of Economic Cooperation and Development) average is the mean of national averages from France, Italy, and Japan. (Reddy and Goldemberg 1990; Schipper and Meyers 1989)

\section{$\underline{\text { Significance of Refrigerator Energy Use }}$}

There are about 125 million refrigerators and freezers in the United States. In the average home, they now are the largest consumers of electrical energy. They use $20 \%-25 \%$, or more than 170 billion kilowatt hours per year, of the total electric load in the residential sector-an amount equal to the entire output of about 20 baseload power plants rated at $1000 \mathrm{MW}$ each (Shepard and Houghton 1990). In other industrialized countries, as well, R/Fs consume considerable power.

In rapidly developing countries, growth in electrical demand is outstripping the capacity of electrical distribution systems. As electrical lines are extended to residences, electricity use assumes shapes remarkably like those seen in industrialized countries, where refrigeration is a major contributor (Figure 1).

As shown in Figure 1, electrical loads per refrigerator vary considerably around the world. In the United Staies $\mathrm{R} / \mathrm{Fs}$ are quite large (about $20 \mathrm{ft}^{3}$ [560 1] refrigerated volume on average), but they are consuming less electricity per unit volume as energy-efficiency standards become increasingly stringent. In other developed countries both $\mathrm{R} / \mathrm{F}$ size (perhaps $12 \mathrm{ft}^{3}$ [340 l] on average) and energy efficiency are moderate. In developing countries $\mathrm{R} / \mathrm{Fs}$ are smaller $\left(7 \mathrm{ft}^{3}\right.$ [200 1$]$ ), very often singledoor, and their energy efficiency is relatively low (Meyers et al. 1990).

Reasons to improve R/F efficiency vary worldwide. In the United States, consumers demanded improved efficiency after the 1970s oil shocks. In response, industry reduced annual energy use of R/Fs from an average of $1700 \mathrm{kWh}$ in 1972 to 1200 $\mathrm{kWh}$ by 1980 (AHAM 1990). Since 1980 industry and government have agreed on 
Potter and Benson / Solar Energy Research Institute / Page 3

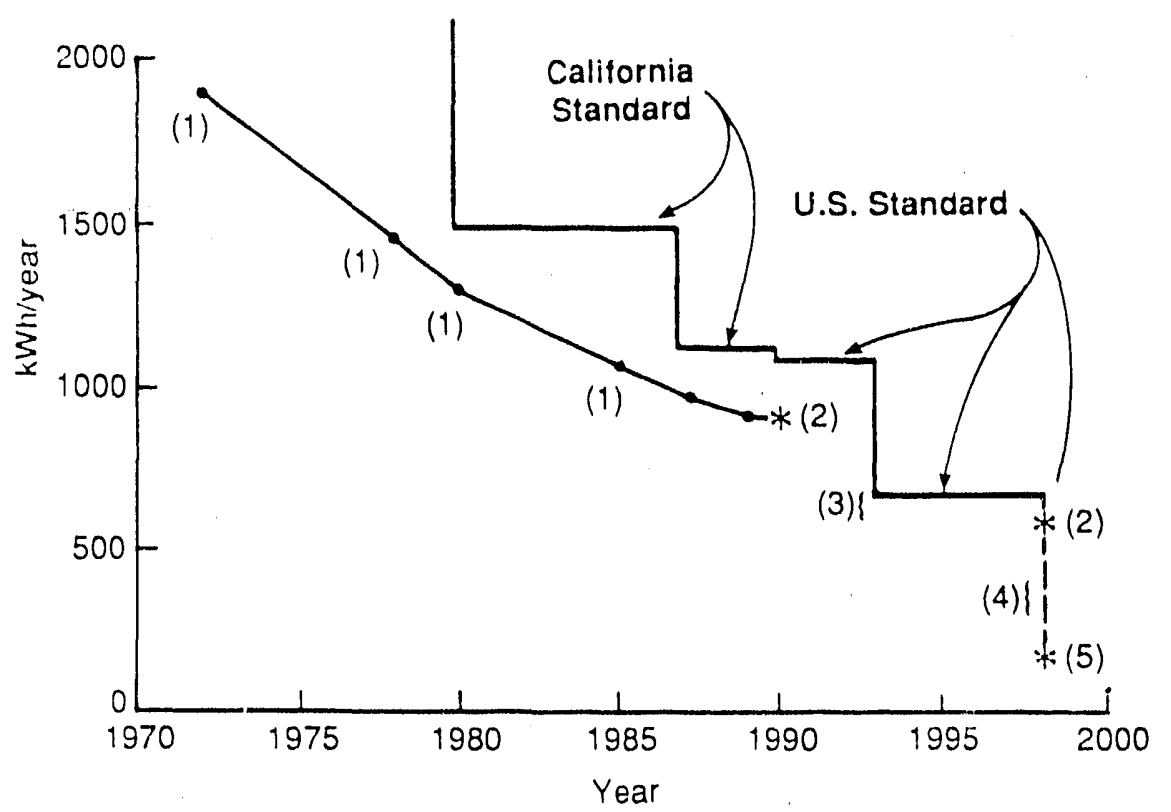

Figure 2. Actual and projected reductions in U.S. refrigerator energy use over a 30-year period, normalized to a 20-cubic-foot top-mount refrigerator/freezer. Based on shipmentweighted energy ratings from 1972 through 1989 (I-AHAM 1990). The projection for 1990 assumed little change from 1989 (2-Turiel 1991). The range projected for 1993 assumed performance as much as $50 \mathrm{kWh} / \mathrm{yr}$, on average, better than the 1993 standard level (3-Schulz 1991). The vertical dashed line in 1998 indicates the effective year for the next standard level, not the level itself, which will be determined in about 1995 based on innovations then considered to be "technologically feasible." One projection for 1998 assumed no further changes from 1993 than incorporation of evacuated panels (2-Turiel 1991). Another projection for 1998 assumed a variety of technologies and incentives (4-Hoffman 1990). A third projection for 1998 assumed implementation of specific refrigerator modifications (5-Goldstein et ab. 1990).

an acceptable schedule for further reductions, codified in the National Appliance Energy Conservation Act (NAECA) (U.S. DOE 1989). NAECA regulations require that annual energy use of the baseline $R / F$ unit be further reduced to $950 \mathrm{kWh}$ by 1990 and to $700 \mathrm{~kW} / \mathrm{h}$ by 1993 . Figure 2 shows recent reductions and progress anticipated under NAECA. Reductions are expected to continue as improved technologies become practicable and because of financial incentives for manufacturers that have been proposed by electric utilities and supported by many, including the U.S. Environmental Protection Agency (EPA) (Hoffman 1990).

Environmental concerns are also gaining increased momentum in other industrialized countries, where similar energy-use reductions probably will be required. This movement will be given additional imperus by the strong international ties maintained by several U.S. manufacturers.

In developing countries, reducing the energy use of refrigerators is problematic, especially given the rapid acceleration toward market saruration. This appliance provides such a great improvement in the living standard, and is so relatively inexpensive to operate (especially if the electric pow' $I$ is subsidized), that the 
consumer has little incentive to reduce energy use. Additionally, older, less-efficient designs are common (Meyers et al. 1990), as are units manufactured by local companies not bound by energy-efficiency guidelines. Finally, newer, energyconserving technologies may not be readily available.

Although it may take longer in developing countries, prudent planners there also may impose tighter standards to discourage wasteful household energy use. They may recognize the increasingly clear relation between electricity use, which can be con. trolled, and global warming (Flavin and Lenssen 1990). Closer to home, utility plan. ners can see how growing demand also worsens air quality (Sathaye and Ketoff 1990), undermines power grid reliability (Meyers et al. 1990), threatens power shortages in the critical commercial and industrial sectors (Jones et al. 1988), and increases capital drain for power plant construction (Fickett, Gellings, and Lovins 1990).

Levels of energy use and the motivation to reduce those levels both vary greatly worldwide. However, the refrigeraror is now, or will become, a likely focus of energyconservation action in both developed and developing countries. Energy-efficiency standards, incentives to manufacturers, and consumer requirements all will play a role.

\section{Importance of Thermal Insulation}

Contrary to popular opinion, the energy use of a household refrigerator is not closely related to how often the door is opened or to the amount of food inside. Rather, between 70\% (Kirby 1990) and 95\% (Benecke 1988) of the electrical load, depending on model and size, is directly related to the thermal performance of the insulated shell. The remaining load is caused mainly by thermal gains through gaskets and from defrost or anti-sweat heaters. For that reason, improved insulation performance by itself can bring about significant overall energy savings by lowering the demand on the chiller subsystem. The following three insulation strategies can reduce energy use:

(1) The thickness (and thus thermal resistance) of a current $R / F$ sidewall insulation can be increased. An advantage of this method is working with known, or related nonCFC, insulation technologies. Disadvantages include the expense of retooling manufacturing lines, undesirable characteristics of altemative foam-expanding gases, and slight loss in consumer utility because of increased exterior or decreased interior dimensions. This option is considered a last resort for manufacturers because $70 \%$ of U.S. purchasers need replacement units to fit an existing space (Leaversuch 1990).

(2) The thermal resistance of a sidewall, but not its thickness, can be increased by replacing some of the current insulation with a better insulator. An advantage is that little or no retooling would be required; a disadvantage is the risk associated with the unknowns of a new technology. However, given that the well-known CFC foamblowing agents will soon be unavailable, it's clear that one new technology or another will result (Smoluk 1990).

(3) A sidewall's thermal resistance can be matched or increased, and its thickness decreased, by completely replacing current insulation with a much better insulator. 


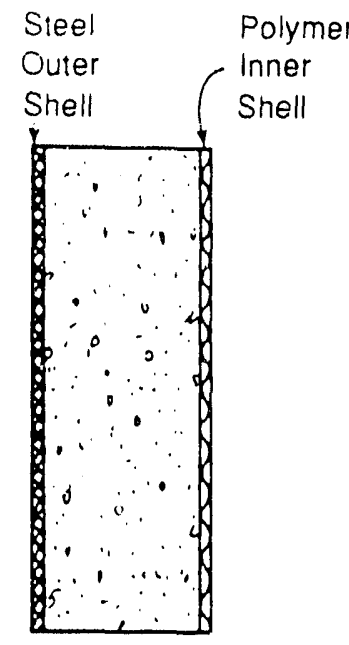

Base Case (CFC Foam)

\section{A. $R 16$}

Wall ga!ns: $150 \mathrm{Btu} / \mathrm{h}$ Annual kWh: 1000

Volume: 20

$\mathrm{kWh} / \mathrm{tt}^{3}$ /year: 50

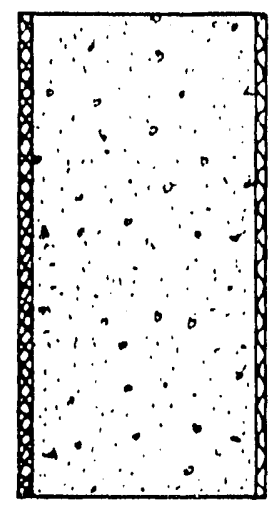

Foam Added

B. $R 24$

Wall gains: $100 \mathrm{Btu} / \mathrm{h}$

Annual kWh: 872

Volume: 18.1

$\mathrm{kWh} / \mathrm{tt}^{3}$ /year: 48.2

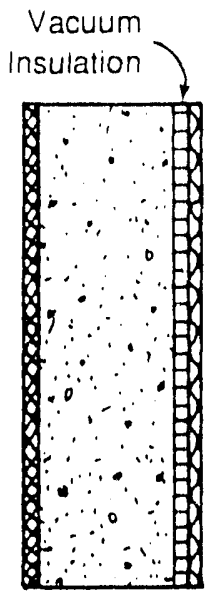

Partial Substitution of Vacuum Insulation for Foam

C. $\mathrm{R} 24$

ivall gains: $100 \mathrm{Btu} / \mathrm{h}$ Annual kWh: 872

Volume: 20

kWh/t 3 /year: 43.6

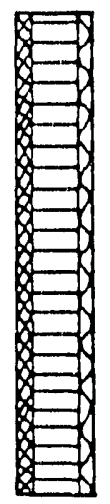

Total Substitution of Vacuum Insulation for Foam

D. $R 24$

Wall gains: $100 \mathrm{Btu} / \mathrm{h}$ Annual kW/h: 872

Volume: 22.8

$\mathrm{kWh} / \mathrm{ft}^{3} /$ year: 38.2

Figure 3. Comparison of options for increasing insulating performance of refrigerator sidewalls. The insulating value of foam is assumed to be $R 8$ in an inch; a hypothetical mid-range vacuum insulation is assumed with an insulating value of $R 10$ in 0.25 inch.

Advantages are that the interior volume thus created is saleable, and energy efficiency also could improve. Possible disadvantages again include retooling costs and the manufacturing and warranty risks of a novel technology.

Figure 3 illustrates these options and indicates the significant improvement in thermal performance that advanced insulation can contribute. It also demonstrates another effect of compact insulation on refrigerator efficiency (calculated as the energy used per unit of chilled volume): it increases the denominator (volume) of the ratio $\mathrm{kWh} / \mathrm{ft}^{3}$, requiring less energy improvement in the numerator to satisfy energy-efficiency standards.

\section{Support for Improved Performance of R/FS}

A number of market factors now encourage the use of better insulation. Perhaps the most pervasive in the United States, beyond efficiency standards, is the increasing influence of an ethic that encourages people to buy refrigerators and other items that are more environmentally benign even though they may be more expensive (Udall and Harvey 1990).

Many electric utility companies, acting on their identification of refrigerator electric loads as controllable, offer a range of incentives for energy efficiency (EPRI 1987; Mataloni and DeVitto 1991). These incentives, aimed at purchasers of high-efficiency 
$\mathrm{R} / \mathrm{Fs}$, are mostly rebate programs that partly or completely offset extra consumer costs of improved models. Actively improving $R / F$ efficiency with new non-CFC technologies can reduce major uncertainties about future electric energy and demand levels (Joyner 1989) by reducing an obvious component of residential consumption.

The "golden carrots" concept affects manufacturers even more directly. This type of incentive program proposes that utilities and other interested parties contribute to a fund that can be distributed among $R / F$ manufacturers whose products exceed NAECA energy guidelines. In 1990, a precedent-setting program in Sweden-which sought R/Fs with efficiency $30 \%-40 \%$ better than the best then on the market-apparently was successful (Morrill 1990). Pacific Gas and Electric started a program in the United States with $\$ 1$ million in August 1990. Other contributions may bring the total to between $\$ 10$ and $\$ 20$ million by December 1991 (Nadel 1991).

In developing countries, support is more likely to come from international public interests like the U.S. Agency for International Development (AID) programs and philanthropic foundations, and from joint-venture private-sector interests who anticipate an expanding international market for improved refrigerator technologies. Governments will also help by purchasing energy-efficient models, strengthening standards, instituting testing and labeling programs, and negotiating with manufacturers for improved designs, components, and operating characteristics.

\section{DEVELOPMENT OF NEW VACUUM INSULATIONS}

\section{Heat Transfer Mechanisms}

To better understand the progression of refrigerator insulation technulogies, it is useful to review briefly the principal methods of heat transfer.

Thermal transfer by conduction depends on molecule-to-molecule energy transfer. For example, in current fiberglass bulk insulations, solid-phase conduction is reduced by greatly extending the thermal path: the spun glass fibers often lie perpendicular to the flow of heat. In insulating foams the thermal path is similarly elongated through solid material, because the polymer walls of the gas-filled cells are relatively thin and not in a direct line from the warm to the cool side of the insulation.

Thermal transfer by convection happens when fluids (gases in couventional R/Fs) circulate and carry more-energetic molecules from warmer to cooler locarions. In bulk insulations volume is broken up into small cells within which convection cannot occur. Foam insulation operates similarly, with the added advantage that the gas chosen for the very small ceil can be of high molecular weight and correspondingly low thermal conductivity.

Thermal transfer by radiation depends on the temperature difference between facing surfaces and the emissivity of those surfaces. Radiation is effectively reduced in bulk insulations by the imposition of many obstructing surfaces between the exterior warm surface and the exterior cold surface. Interim absorption and reradiation in all 
directions slows thermal transfer. Foam insulation also has multiple surfaces that block direct radiational heat transfer from the warmer to the cooler surface.

\section{Altemative Advanced Thermal Insulation Designs}

Several vacuum insulation concepts currently are being considered for refrigerator use; they can easily be compared by examining their respective choices of envelope and filler materials.

Outside: The gas-impermeable envelopes can consist of polymer films, metal foils, or thicker sheet metal. The performance of thin polymer films and foils in other thermal insulation uses has suggested their application as multilayer vacuum-tight envelopes. Manufacturing ease and expense may not be a problem because the material is familiar and in current wide use. Rapid, reliable joining and long-term gas impermeability are technical issues now being examined.

Monolithic but thin metal envelopes can be vacuum-tight (like the thicker all-steel vacuum bottles) and can be joined rapidly and hermetically. If methods can be developed to reduce their weight and cost, they can be widely used to enclose thin vacuum insulation panels.

Inside: Filler materials can include layers of polymer film, gels and powders, spacer arrays, or perhaps some combination of these. Materials that can be compressed to be quite strong and that combine extremely small cell spaces with very long thermal conduction paths (thereby reducing convection and conduction) can fill either type of envelope. Powders and aerogels, which can be specially formulated to reduce radiative heat transfer, are appropriate for this application, and work continues on low-cost and reliable fabricarion techniques.

Spacer arrays provide discrete contacts with the envelope and very limited solid conduction paths. Rapid, reliable fabrication techniques must be developed if this approach is to be broadly practical.

\section{Comparison of Performance}

The state of the art in designing and building insulations that incorporate these innovative concepts is changing rapidly. Reliable methods for testing the flat, thin, low-thermal-conductance insulations are also being developed. Thus, current conclusions by developers and testers are necessarily tentative. However, precedent in testing other types of insulating assemblies and some gross energy-use tests have provided results that are accurate enourh to monitor progress. Sufficient information also now exists in the literature, and from the developers themselves, to compare current performance and future objectives of the different conceptual approaches to vacuum insulation.

Vacuum powder insulation samples in polymer and foil laminate envelopes have repeatedly tested at between R15 and R25 per inch (Fine 1989). Vacuum powders in 
a monolithic metal enveiope also have been examined extensively, with similar results for large samples (Schilf 1990). Tests in which the powders are more opaque (opacity further reduces thermal transfer by radiation) may show even better results.

Siilica aerogel, a very low density microporous glass, in slabs, has tested under vacuum conditions at $\mathrm{R} 20$ per inch of nonenclosed bulk. Within polymer film envelopes with metal reflective layers it has tested at R15 to R16 per inch (Martin 1990). Improvements in performance are anticipated if small, oriented metal platelets can be introduced to this or other proposed gel systems to reduce thermal radiation.

Vacuum array insulation uses discrete spacer contacts to resolve the thermal and structural issues simultaneously. Samples, most often made in thin sections, have tesied at R5 in sections whose maximum thickness is about 0.2 in. Nested samples have tested at R10 in sections with maximum thickness of about 0.25 in. This suggests that stacking vacuum array insulation is as effective as adding more filler to other vacuum insulations. These tests have been of relatively small laboratory samples (less than $0.5 \mathrm{~m}^{2}$ ) with guard heaters that ensured no edge losses (Benson 1990). Thermal "short circuits" occur at the edges of all insulation designs that use monolithic steel envelope materials; these results are especially noticeable in small prototypes. Although edge designs that extend the thermal paths reduce the effect somewhat, larger samples (greater than $1 \mathrm{~m}^{2}$; the size likely to be found in $\mathrm{R} / \mathrm{Fs}$ ) probably will be necessary in most cases to resolve the issue in practical terms. The important issue is to reduce to a reasonable minimum edge losses as a proportion of total losses.

The real proof of performance is in the sidewall of a refrigerator or freezer, where the arrangement of panels and/or the augmentation provided by foam polymer insulation may be sufficient to overcome the edge losses. Such practical test results are extremely sketchy at this time, but they indicate that reasonably large vacuum array panels, when installed in advance of the foaming process, reduce the thermal transfer through the sidewalls about as would be expected if edge effects were not appreciable (Kirby 1990).

An additional benefit is that the metal envelope of this insulation could also serve as the R/F's steel exterior shell. In one test of a district hearing system in Berlin, the walls of the pipe are also the envelope walls of the vacuum insulation (Schilf 1990). This mechanical characteristic of vacuum insulation, in metal-envelope panel form, could greatly simplify basic design and construction of energy-efficient refrigerators - a major benefit to manufacturers and consumers in both industrialized and developing countries.

\section{Potential for Cost Effectiveness}

The practicality of these new insulations depends on thermal performance, cost added to a R/F, and the benefit to be gained from their compactness. Figure 4 describes the cost that compactness may require based on the cost and performance data that follow.

Total cost is often determined by adding together typical costs of component parts and 


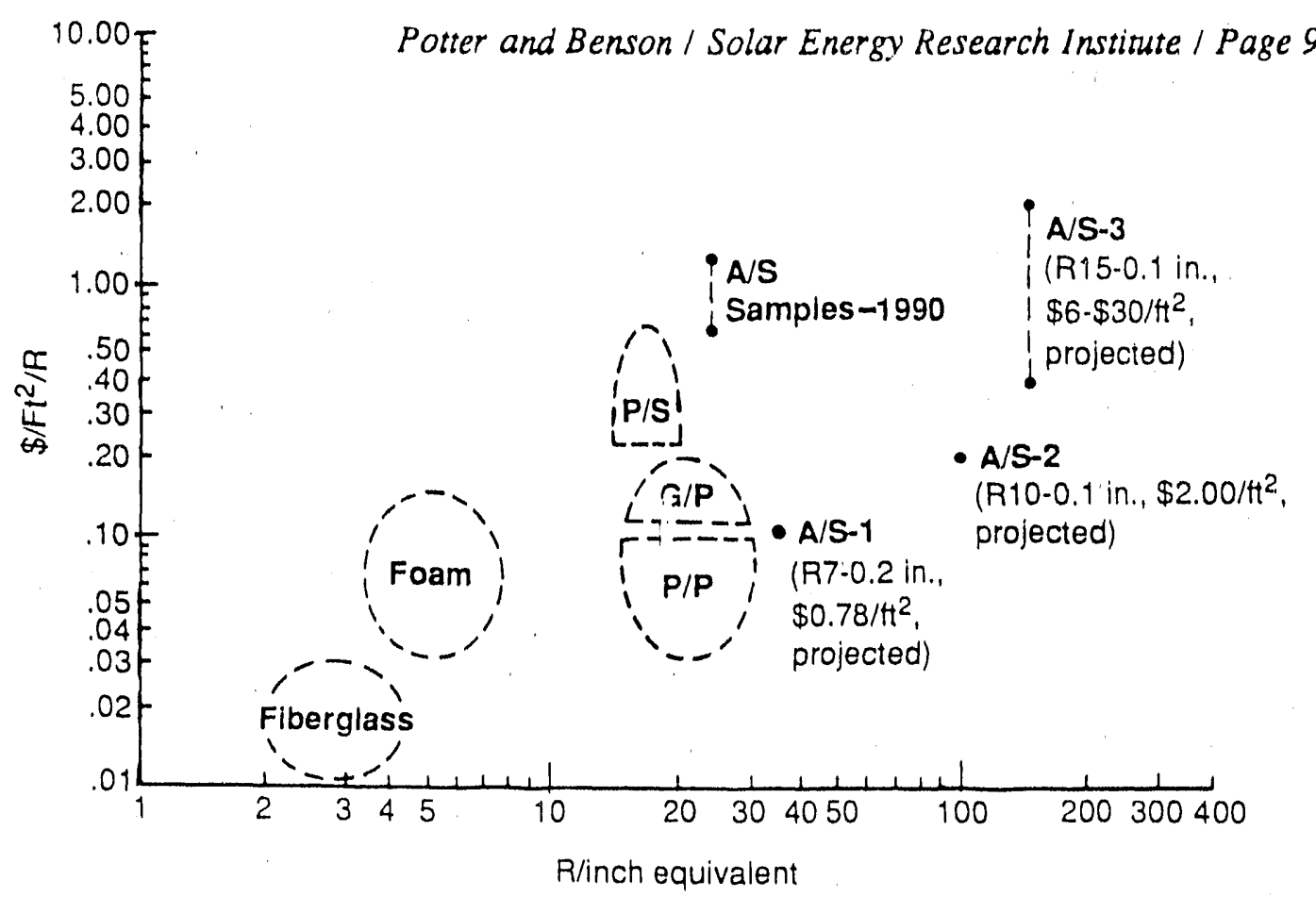

Figure 4. Cost of insulation compactness for flat panels, showing relationship of relatively new polymer foams to fiberglass, displaced by the more expensive foam in applications in which volume was highly valued. As energy-efficiency standards are tightened, a similar move to one or more of the vacuum insulations is likely. Cost and performance estimates are shown for $A / S-2$ and $A / S-3$ to indicate only the technological trend, the farther reaches of which are likely to find little use in appliances. (P/P: powder-filled polymer envelope. G/P: aerogel-filled polymer envelope. P/S: powder-filled monolithic steel envelope. A/S: spacer array within menolithic steel envelope.)

estimated costs of manufacturing. However, because all of these concepts are still undergoing performance-improving modification, finished designs are not available for such an exercise. Rather than speculate about current and possible future configurations, we will use projected manufacturing costs provided by the researchers themselves, where available. This should not be considered a comprehensive treatment of all possibilities, but it will allow comparison of current designs.

1. Powder-filled polymer envelope (P/P). With a precipitated silica filler material, relatively thick polymer film envelope, and uncertainty about costs for reliable filling and sealing procedures, manufacturing costs of $\$ 1.50 / \mathrm{ft}^{2}$-in. are projected (Fine 1990). Assuming reduced gas permuance of future polymers and the development of reliable automated manufacturing methods, researchers speculate that costs will be as little as $\$ 0.60$ to $\$ 0.90 / \mathrm{ft}^{2}$-in. (Fine 1990; Barito 1991). With an R-value of 15 to 25 per inch assumed, these costs translate to about $\$ 0.03$ to $\$ 0.10 / \mathrm{ft}^{2}$ per $\mathrm{R}$.

2. Aerogel-filled polymer envelope (G/P). With a silica aerogel slab filler material, thin polymer cuvelope, and some uncertainty about costs for mass manufacture of the aerogel, researchers project manufacturing costs of $\$ 2.00-\$ 3.00 / \mathrm{ft}^{2}$-in. (Martin 1991). Developers are reluctant to assume cost reductions beyond this value until further production experience is gained. With an $\mathrm{R}$-value of 15 assumed, this range of costs translates to $\$ 0.13-\$ 0.20 / \mathrm{ft}^{2}$ per $\mathrm{R}$ value. 
3. Powder-filled monolithic steel envelope $(\mathbf{P} / \mathrm{S})$. With a diatomaceous earth filler material and 15-mil stainless steel envelope, manufacturing costs of $\$ 6.25$ to $\$ 10.00 / \mathrm{ft}^{2}$-in. are projected. By changing the envelope material to mild steel and maintaining a similar manufacturing method, researchers have speculated, costs can be as little as $\$ 4.25$ to $\$ 7.50 / \mathrm{ft}^{2}$-in. (Merriam and Aguilar 1990; Schilf 1991). With an R-value of 15 to 20 per inch assumed, these costs translate to $\$ 0.21-\$ 0.67 / \mathrm{ft}^{2}$ per $R$ value. However, they are not directly comparable because they include substitution for the inner and outer shells of a refrigerator.

4. Spacer array within a monolithic steel envelope (A/S). With a discrete glass sphere spacer array within an 0.008-in.-thick stainless steel envelope, manufacturing costs of $\$ 2.00 / \mathrm{ft}^{2}$ are projected. By changing the envelope material to mild steel, and maintaining the same spacer array' placement, costs of as little as $\$ 0.78 / \mathrm{ft}^{2}$ have been speculated for a 0.2-in.-thick panel (Short 1990). With an R-value of 6 to 10 per panel assumed, these costs translate to $\$ 0.08-\$ 0.33 / \mathrm{ft}^{2}$ per $\mathrm{R}$ value.

Specific benefits of the new insulations cannot be quantified until detailed thermal analyses are available to enable comparisons among designs, components, and improvements. However, these statements describe the general situation:

Any one of several vacuum insulations, incorporated into existing foam refrigerator sidewall configurations, would sufficiently decrease heat flow that this modification alone would enable units to meet the 1993 NAECA energy-efficiency standards. No production-line retooling would be necessary; the cost per appliance would be only that for an added R10 of insulation. Assuming $40 \mathrm{ft}^{2}$ of insulatable area, additional manufacturing cost would be between $\$ 12.00$ and $\$ 80.00$, considering the range of costs projected above for comparable vacuum insulations by their develnpers.

Alternatively, if vacuum insulation displaced all the foam in a redesigned sidewall, it would maintain thermal integrity and create additional refrigerated volume where insulating foam had been. The added saleable volume would offset some or all of any necessary retooling expense. At $\$ 45.00 / \mathrm{ft}^{3}$ retail cost for refrigerated volume (reduced in our calculations to nominally $\$ 15.00 / \mathrm{ft}^{3}$ manufacturing cost credit), the manufacturing cost balance could range between a net savings of about $\$ 20.00$ and a net cost of $\$ 185.00$ for $R 24$ of the comparable vacuum insulations described above.

Vacuum insulation technologies must, of course, be reliable, and methods currently used to maintain and test vacuum levels are not adequate for some of the new designs. Prospects for improved reliability will be enhanced if government agencies and industry leaders accelerate their involvement in research and testing. Such involvement has already increased in several ways in the past year or so, particularly with the initiation of the Appliance Industry-Government CFC Replacement Consortium (Somheil 1990).

Costs of the vacuum insulations must be better defined, and that will be possible if development and testing are expedited at different production levels. Industry can actively support development of the vacuum insulation alternatives by defining practical requirements and by buying and evaluating test artir!es. 


\section{CONCLUSIONS}

Popular and institutional support is growing for improvements in the energy efficiency of household refrigerators. Government and industry are developing a number of novel vacuum insulation approaches that can bring about reductions in energy use while replacing CFC-blown insulating foams. These reductions could allow practical compliance with energy-efficiency legislation. Technical and practical challenges face the developers of the alternatives, and commercialization may require increased participation by government and industry. It is particularly important to improve and validate cost effectiveness so that these approaches will be broadly accepted. With industry assistance, several of the vacuum-insulated designs could be on the market within ten years, and energy use by refrigerators could cease to be a significant issue. This would be a "first" for the conservation technology research effort. It would provide far-reaching benefits to consumers and manufacturers worldwide and would greatly reduce stress on the environment.

\section{ACKNOWLEDGMENTS}

The authors gratefully acknowledge support and guidance from the Department of Energy's Office of Buildings Technologies, Building Systems and Materials Division, under Contract No. DE-AC02-83CH10093. Major in-kind assistance was provided by individual members of the refrigerator and steel industries.

\section{REFERENCES}

Association of Home Appliance Manufacturers (AHAM), "Energy Efficiency and Consumption Trends," Chicago, IL. April 1990.

Author Linknown, "Recommendations for the Design and Construction of Energy-Efficient Household Refrigerators and Freezers, Commercial Refrigerated Cabinets and Chilling Equipment for Supermarkets," Review Draft, Munich, FRG, Supt. 1988.

Barito, R., R. W. Barito \& Assoc., Inc., Louisville, KY. Personal commun., Jan. 1991.

Benson, D. K., notes for presentation to CVI Industry Review Panel meeting. June 1990.

Electric Power Research Institute (EPRI), "A Compendium of Utility-Sponsored Energy Efficiency Rebate Programs," Palo Alto, CA. 1987.

Fickett, A. P., C. W. Gellings, and A. B. Lovins, "Efficient Use of Electricity," Scientific American, pp. 65-74. Sept. 1990.

Fine, H. A., "Advanced Evacuated Thermal Insulations: The State of the Art," Journal of Thermal Insulation, vol. 12. Jan. 1989.

Fine, H. A., "Advanced Insulations for Appliances," 1990 International Conference on CFC and Halon Alternatives, tape no. 67, Baltimore, MD. Nov. 29, 1990.

Flavin, C., and N. Lenssen, "Beyond the Petroleum Age: Designing a Solar Economy," Worldwatch Paper 100, Worldwatch Institute, Washington, DC. Dec. 1990.

Goldstein, D., R. Mowris, B. Davis, and K. Dolan, "Initiating Lease-Cost Energy Planning in California: Preliminary Methodology and Analysis," testimony by Natural Resources Defense Council and the Sierra Club to the California Energy Commission, Docket 88-ER-8, Feb. 1990. 
Hoffman, J., "Super-Efficient Refrigerawrs: The Potential of Advanced Technrıogy to Provide Low Cost Demand Reductions and Profilab'e Pollution Prevention Through a Program of Early Retirement, 1990 Competitek Forum, Rocky Mountain Institute. Sept. 1y90, revised INov. 1990. Jones, D. W., A. P. Sanghvi, and E. L. Hillsman, "The Impacts of Inadequate Electricity Supply in Developing Counuries," Oak Ridge National Laboratory Report No. ORNL-6436. Aug. 1988.

$J$, yner, P., "Utility Impacts and Perspectives," notes for presentation to the CFC Alltematives Conference, Alexandria, VA. Electric Power Research Instiute, Nov. 1989.

Kirby, D., Whirlpool, Inc., presentation at CVI Industry Review Panel meeting. June 1990.

Leaversuch, R., "Total Redesign of Refrigerators Now Is Inevitable," Modern Plastics, p. 68. Oct. 1990.

Martin, M., Thermalux. Inc., Richmond, CA. Personal commun., Jan. 1991.

Mataloni, L., and D. DeVituo, "Sırvey on Utility Incentive Programs for Efficient A.ppliances," conducted by ICF Resources Inc. for Pacific Gas and Electric. Jan. 1991.

Merriam, D., and J. Aguilar, "Discussion of Powder Insulation Technologies: MBB Concept," A. D. Litule, Inc. Jan. 1990.

Meyers, S., S. Tyler, H. Geller, J. Sathaye, and L. Schipper, "Energy Efficiency and Househoid Electric Appliances in Developing and Newly Industrialized Countries," Lawrence Berkeley Laboralory Report No. LBL-29678. Dec. 1990.

Morrill, J., in "The Golden Carrot News," Number 1, American Council for an Energy Efricient E.conomy (ACEEE), Washington, DC. Sept. 1990.

Nadel, S., American Council for an Energy Efficient Economy, Washington, DC, personal commun., Jan. 1991.

Reddy, A.K.N., and J. Goldemberg, "Energy for the Developing World," Scientific American, pp. 111-118. Sept. 1990.

Sathaye, J., and A. Ketoff, " $\mathrm{CO}_{2}$ Emissions from Major Developing Countries: Better Understanding the Role of Energy in the Long Term," Interim Reporh, Lawrence Berkeley Laboratory Report No. LBL-29507. Aug. 1990.

Schilf, L., ASHRAE Serninar "Vacuum Alternatives for Energy-Efficient Insulations," St. Louis, MO. June 1990.

Schilf, L., MBE, Delmenhorst, FRG. Personal commun., Jan. 1991.

Schipper, L., and S. Meyers, "Improving Appliance Efficiency in Intionesia," draft of paper prepared for Energy Policy. Oct. 1989.

Schulz, C., Association of Home Appliance Manufacturers (AHAM), personal commun., Jar. 1991.

Shepard, M., and D. Houghton, "Residential Equipment," in The State of the Art: Appliances, Rocky Mountain Institute. Aug. 1990.

Shor, W., CVI Industry' Review Panel meeting. June 1990.

Smoluk, G. R., "Thermally Insulative Foam: More Shape-Up Than Shakeout." Modern Plastics, pp. 42-44. Feb. 1990.

Somheil, T., "Optimum Alternatives," Appliance, pp. 26-30. June 1990.

Turiel, I., Lawrence Berkeley Laboratory. Personal commun., Jan. 1991.

Udall, R., and K. Harvey (eds.), "Does Abating Global Warming Cost or Save Money?" in Rocky Mountain Institute Newsletter, vol. 61, no. 3, pp. 1-3, Old Snowmass, CO. Fall/Winter 1990.

U.S. Deparment of Energy (DOE), Office of Conservation and Renewable Energy, "Energy' Conservation Standards for Consumer Products: Refrigerators, Fumaces and Television Sets," 10 CFR Par 430. Nov. 1989. 


\section{S.I. CONVERSIONS}

\begin{tabular}{|c|c|c|c|}
\hline Attribute & Unit & Factor & S.I. Unit \\
\hline $\begin{array}{l}\text { Thermal resistance } \\
\text { Example: }\end{array}$ & $\begin{array}{l}\mathrm{R}\left(\mathrm{hr}-\mathrm{ft}^{2}-\mathrm{F} / \mathrm{Btu}\right) \\
\mathrm{R} 10\end{array}$ & $\times 0.176$ & $\begin{array}{l}\mathrm{R}\left(\mathrm{m}^{2} \mathrm{KW}^{-1}\right) \\
\mathrm{R} 1.76\end{array}$ \\
\hline $\begin{array}{c}\text { Electrical energy } \\
\text { Example: }\end{array}$ & $\begin{array}{l}\text { watt-hour (Wh) } \\
170 \text { billion } \mathrm{kWh}\end{array}$ & $\times 3600$ & $\begin{array}{l}\text { Joules } \\
6 \times 10^{17} \text { Joules }\end{array}$ \\
\hline $\begin{array}{l}\text { Length } \\
\text { Example: }\end{array}$ & $\begin{array}{l}\text { inch } \\
0.2 \text { inch }\end{array}$ & $\times 2.54$ & $\begin{array}{l}\text { centimeter }(\mathrm{cm}) \\
0.508 \mathrm{~cm} \\
\end{array}$ \\
\hline $\begin{array}{l}\text { Volums } \\
\text { Example: }\end{array}$ & $\begin{array}{l}\mathrm{ft}^{3} \\
20 \mathrm{ft}^{3}\end{array}$ & $\times 0.028$ & $\begin{array}{l}\mathrm{m}^{3} \\
0.57 \mathrm{~m}^{3} \\
\end{array}$ \\
\hline $\begin{array}{l}\text { Normalized insulation cost } \\
\text { Example: }\end{array}$ & $\begin{array}{l}\$ / \mathrm{ft}^{2} \mathrm{R} \\
\$ 1 / \mathrm{ft}^{2} \mathrm{R}\end{array}$ & $\times 61.1$ & $\begin{array}{l}\$ W m^{-4} K \\
\$ 61 \mathrm{Wm}^{-4} \mathrm{~K}\end{array}$ \\
\hline $\begin{array}{l}\text { Apparent thermal conductivity } \\
\text { Example: }\end{array}$ & $\begin{array}{l}\mathrm{k}(\mathrm{Btu} / \mathrm{it}-\mathrm{hr}-\mathrm{F}) \\
8.7 \mathrm{Btu} / \mathrm{ft}-\mathrm{hr}-\mathrm{F}\end{array}$ & $\times 1.73$ & $\begin{array}{l}k\left(W^{-1} k^{-1}\right) \\
15 \mathrm{Wm}^{-1} \mathrm{k}^{-1}\end{array}$ \\
\hline
\end{tabular}



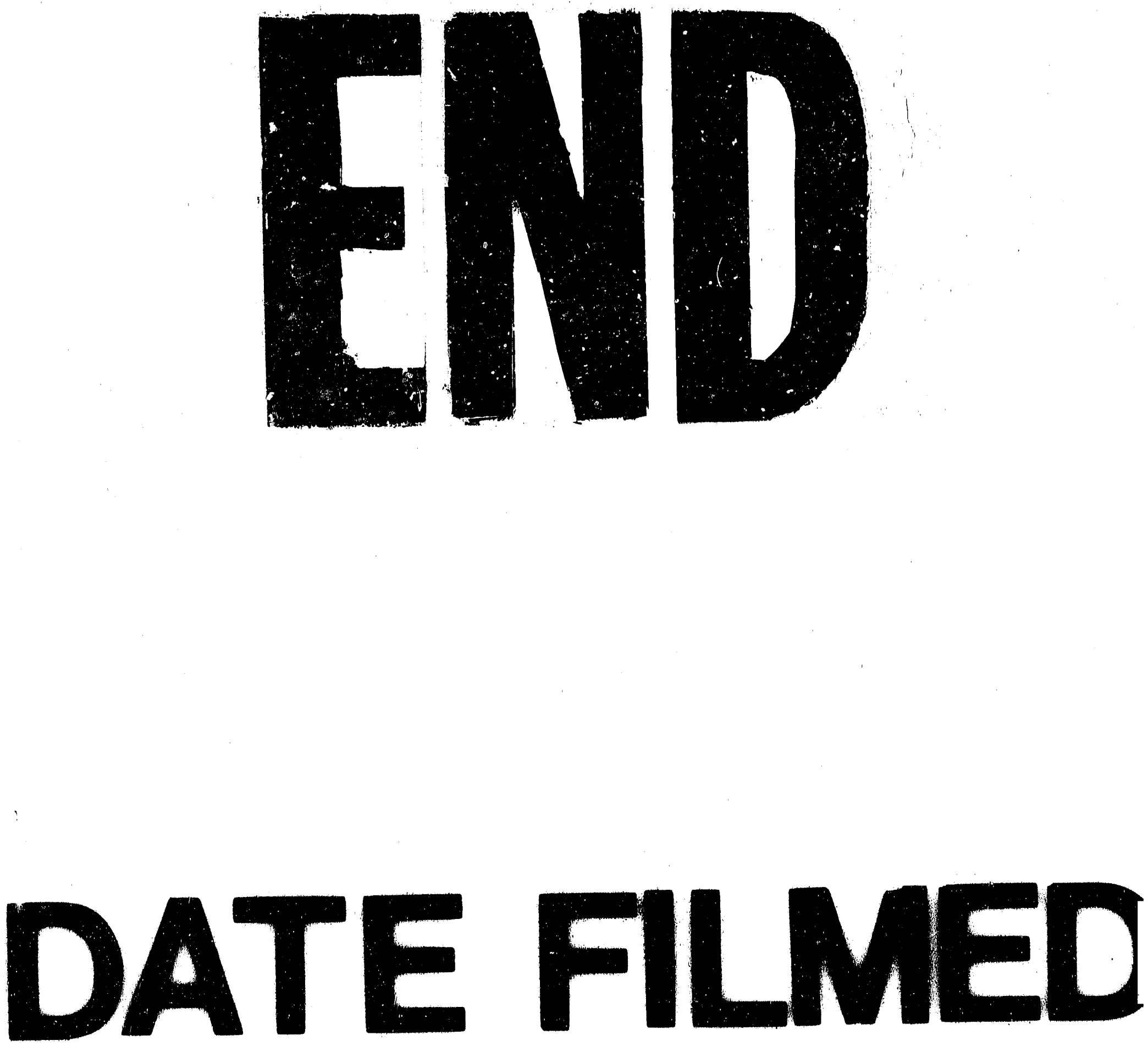

$=$
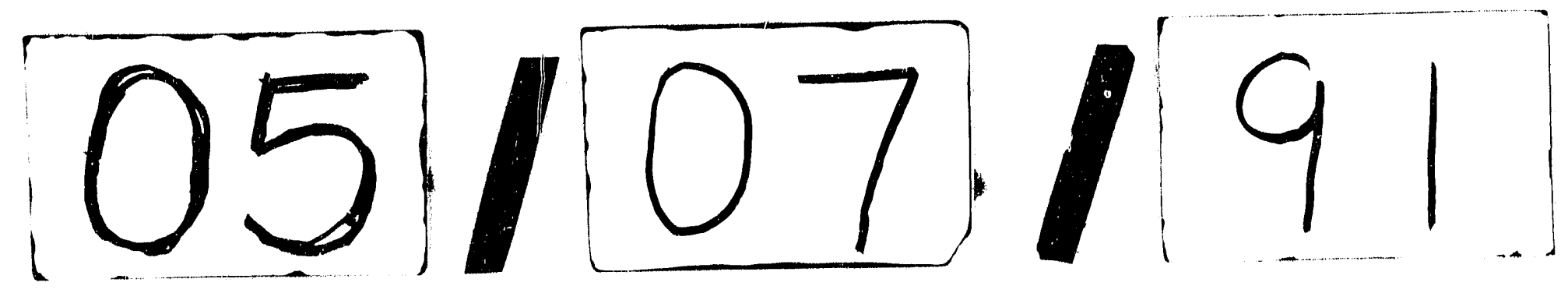
